\title{
Determining heavy metal contamination of road dust in Delhi, India
}

\author{
P. V. SURYAWANSHI, B. S. RAJARAM, A. D. BHANARKAR and C. V. CHALAPATI RAO \\ Air Pollution Control Division, CSIR-National Environmental Engineering Research Institute, \\ Nehru Marg, Nagpur 440020 \\ Corresponding author: A. D. Bhanarkar; email: ad_bhanarkar@neeri.res.in
}

Received: February 2, 2016; accepted: May 3, 2016

\begin{abstract}
RESUMEN
La contaminación del aire es considerada como uno de los mayores desafíos ambientales debido a sus efectos sobre los ecosistemas y la salud humana. En este estudio se investigan los niveles de concentración y las fuentes de la contaminación por metales pesados en muestras de polvo de caminos recolectadas en varios sitios que incluyen áreas con cuatro actividades diferentes en Delhi, India: industriales, carreteras, residenciales y de uso mixto. El contenido de metales en polvo de caminos se analizó mediante espectroscopia de emisión atómica por plasma de acoplamiento inductivo. Los resultados muestran altos niveles de concentración de $\mathrm{Ni}, \mathrm{Cr}$ y $\mathrm{Pb}$ en áreas industriales. Los coeficientes de correlación de Pearson acoplados con análisis de componentes principales revelaron que el $\mathrm{CD}$, el $\mathrm{Cr}$, el $\mathrm{Ni}$ y el $\mathrm{Pb}$ están vinculados con fuentes industriales en tanto que el Zn y el Cu proceden principalmente del tráfico vehicular. La contaminación en polvo de caminos se valoró a través de varios métodos: grado de contaminación, índice ecológico e índice de contaminación. El análisis de los factores de contaminación reveló que las muestras de polvo de caminos estaban contaminadas de manera considerable con $\mathrm{Zn}$ y Pb. Los índices de potencial ecológico indicaron la presencia de contaminación significativa por $\mathrm{Cd}$ y moderada por $\mathrm{Pb}$ en el polvo de camino, en tanto que la contaminación por $\mathrm{Cr}, \mathrm{Cu}, \mathrm{Ni}$ y $\mathrm{Zn}$ fue baja. El índice de contaminación de la mayoría de los metales fue mayor a 1, lo cual revela un deterioro en la calidad del polvo de caminos en Delhi a causa de las emisiones antrópicas. El grado de contaminación, el índice de potencia ecológico y el índice integrado de contaminación indican que el polvo de caminos en áreas industriales, de carreteras y de uso mixto exhiben alta contaminación por metales pesados. El polvo del camino también está contaminado de manera significativa. Evaluaciones realizadas por diversos métodos indicaron que todas las técnicas son importantes para valorar la calidad ambiental.
\end{abstract}

\begin{abstract}
Air pollution has been considered one of the major environmental challenges because of its effect on ecosystems and human health. The concentration levels and sources of heavy metals contamination were studied in road dust samples collected from various locations including four different activity areas: industrial, highways, residential and mixed use in Delhi, India. Metal content in road dust was analyzed by inductively coupled plasma atomic emission spectroscopy. The results showed high concentration levels of $\mathrm{Ni}, \mathrm{Cr}$ and $\mathrm{Pb}$ in industrial areas. Pearson's correlations coupled with principal component analysis revealed that $\mathrm{Cd}, \mathrm{Cr}, \mathrm{Ni}$ and $\mathrm{Pb}$ are associated with industrial sources whereas $\mathrm{Zn}$ and $\mathrm{Cu}$ are mainly contributed by vehicular traffic. Road dust contamination was assessed by various methods: degree of contamination, potential ecological index and pollution index. Contamination factor analysis showed that road dust samples are significantly contaminated by $\mathrm{Zn}$ and $\mathrm{Pb}$. The potential ecological indices indicated high contamination of $\mathrm{Cd}$ and moderate contamination of $\mathrm{Pb}$ in road dust, but low contamination of $\mathrm{Cr}$, $\mathrm{Cu}, \mathrm{Ni}$ and $\mathrm{Zn}$. The pollution index of most of the metals was higher than 1, indicating deterioration of road dust quality of Delhi city due to anthropogenic emissions. The degree of contamination, the potential ecological index and the integrated pollution index reveal that road dust from industrial, mixed use and highway areas are highly contaminated by heavy metals. The road dust from the residential area is also contaminated considerably. Evaluations by various methods indicated that all assessment methods are important for environmental quality evaluation.
\end{abstract}


Keywords: Correlation analysis, ecological risk index, pollution index, principal component analysis, toxic elements.

\section{Introduction}

Due to accelerated industrialization and urbanization, nearly half of the population in the world now lives in urban agglomerations. These intensive activities resulted in increasing quantities of contaminants into the urban environment. Consequently, a variety of environmental problems have cropped up and toxic metal pollution has become a major issue, especially in urban air, soils and road dust (Bilos et al., 2001; Madrid et al., 2002; Han et al., 2006). Road dust is a complex mixture of particles and may contain various components like organics, heavy metals, other inorganics, mould spores, animal dander, pollen, pollen fragments etc., which can possibly get resuspended due to movement of vehicles and wind, resulting in an important source of atmospheric air pollution. It was observed that the particles and associated metals, particularly with fine dust, remain suspended in air longer under certain meteorological conditions. Road dust, an important environmental indicator of metal contamination from atmospheric deposition, receives varying inputs of anthropogenic metals from various stationary and mobile sources such as vehicular traffic, industrial activities, power plants, residential fossil fuel burning, waste incineration, construction and demolition activities, and resuspension of contaminated soil (Bilos et al., 2001; Charlesworth et al., 2003; Bhanarkar et al., 2005, 2008; Gupta et al., 2012). Road dust, therefore, is a significant contributor of pollution in the urban environment. The adverse effects of poor environmental conditions on human health are most evident in urban environments, particularly in developing countries where urbanization, industrialization and rapid population growth are taking place on an unprecedented scale (Duzgoren-Aydin, 2007).

Toxic metals in urban areas are a subject of great concern, due to their non-biodegradable nature and long residence time. The prolonged presence of the contaminants in the urban environment, particularly in road dust, and their close proximity to the human population significantly increase the exposure of the urban population to metals via inhalation, ingestion, and dermal contact (Mielke et al., 1998; Abrahams, 2002). Metals can accumulate in fatty tissues, affecting the functions of organs and disrupting the nervous system or the endocrinal system (Waisberg et al., 2003; Duzgoren-Aydin, 2007) and some metals could cause mutagenic, teratogenic and carcinogenic effects in living beings (Lienesch et al., 2000; Cook et al., 2005).

Although several studies on metal pollution in road dust have been carried out in developed countries (de Miguel et al., 1997; Arslan, 2001; Rasmussen et al., 2001; Charlesworth et al., 2003; Sezgin et al., 2003; Tokalioglu and Karta, 2006; Shi et al., 2008; Amato et al., 2009), very little information is available on this topic in developing countries. Only few studies on quantification and distribution of metals in road dust have been conducted recently in Indian cities (Chatterjee and Banerjee, 1999; Banerjee, 2003; Rawat et al., 2009; Rajaram et al., 2014).

Considering the above, the main objectives of this study include: (1) determination of heavy metals concentration in road dust in various urban environments of Delhi, (2) identification of the possible sources of metals in road dust through statistical analysis and (3) assessment of the metal contamination in urban road dust by various methods.

\section{Materials and methods}

\subsection{Study area}

Delhi, the capital of India, is a major center of international and domestic activities in the Asian subcontinent. It is spread over a $1483 \mathrm{~km}^{2}$ area with a population of about 16.7 millions (GOI, 2011). Rapid urbanization and industrialization of the city resulted in growth of vehicular population in the city. There has been an exponential growth in vehicular fleet, which increased from 3.05 million in 1998-1999 to 6.3 million in 20082009 , thereby registering an overall annual compound growth rate of $7.52 \%$. Delhi has about 85 private cars per 1000 inhabitants (Government of NCT Delhi, 2010). The total distance traveled by all categories of vehicles in the city is estimated to be about 79.2 million $\mathrm{km}$. Out of the above, two-wheelers and four-wheelers (car/van) account for a major share of $42.7 \%$ and $38 \%$ respectively. Three-wheelers and local buses account for about $11.8 \%$ and $3.6 \%$ of vehicular fleet in Delhi respectively, whereas the share of light commercial 
vehicles (LCV) and heavy commercial vehicles (HCV) together account for about 3.2\% (GOI, 2002). Besides the vehicular fleet, the city has five power plants and 33 industrial estates in which many medium-scale and small-scale industries that include chemical, pharmaceutical, automobile part manufacturing, and rubber and plastic manufacturing are present.

\subsection{Sample collection and analysis}

Road dust samples were collected in winter 2009 from nine locations with due consideration to different representative aspects of urban environment in the metropolis including industrial (IND), national highway (HW), residential (RES) and mixed use (MIX) areas (Fig. 1). Samples of road dust were collected by using a vacuum cleaner. A representative composite bulk sample for every sampling location was obtained by taking subsamples from three points of the road at each location and then mixing thorough1y. Description of sampling locations is presented in Rajaram et al. (2014).

All samples were dried in the oven at $110^{\circ} \mathrm{C}$ for $48 \mathrm{~h}$ and sieved through 200 mesh sieve. The sieved dust samples were analyzed for metal content according to standard methods (US-EPA, 1999). Measurement of metal concentrations, i.e. $\mathrm{Cd}, \mathrm{Cr}, \mathrm{Cu}, \mathrm{Ni}, \mathrm{Pb}$, and Zn was carried out using inductively coupled plasma atomic emission spectroscopy (ICP-AES) (Jobin Yvun, model JY24). Calibration standards were prepared through serial dilution of standard stock solution of multi-elements having concentrations of $1000 \mathrm{mg} \mathrm{L}^{-1}$ (Merck, Cat. No. 111355). Standard

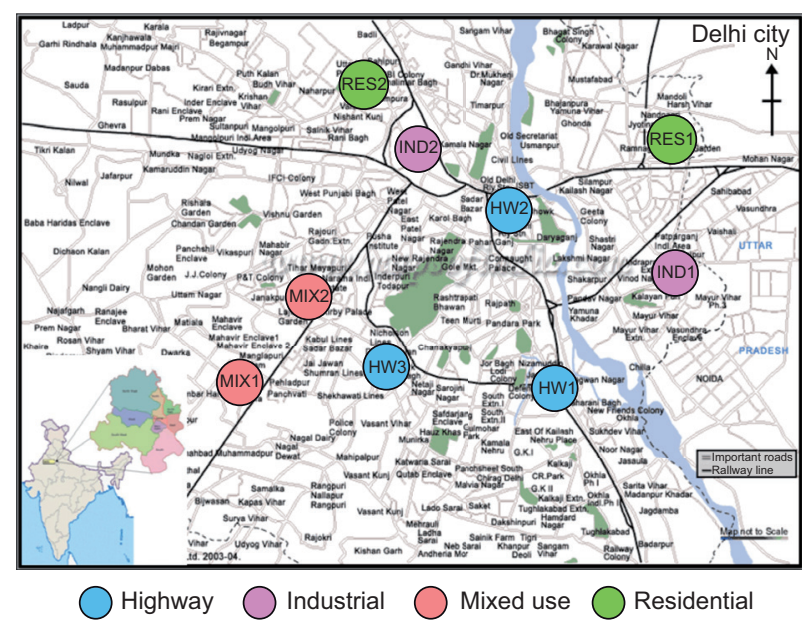

Fig. 1. Map of the study area showing sampling locations. solutions were used to validate the analytical method. All extractions and analysis were made with replicate samples $(n=3)$ and the mean values were reported. The details of sampling and analysis methodology are presented in a previous study (Rajaram et al., 2014).

\subsection{Statistical analysis}

In this study, for the identification of the relationship between metals and their possible sources, Pearson's correlation coefficient analysis and principal components analysis (PCA) were performed using commercial statistics software package SPSS (version 17.0 for windows). The correlation coefficient measures the strength of the interrelationship between two metals.

PCA is the most common multivariate statistical method used in environmental studies to reduce the data while retaining important information and to extract a smaller number of independent factors (principal components, PCs) that can be easily interpreted for analyzing relationships among the observed variables (Massart et al., 1997; Malinowski, 2002; Loska and Wiechuya, 2003; Tokalioglu and Kartal, 2006). PCA starts with the correlation matrix describing the dispersion of the original variables and extracting the eigenvalues and eigenvectors ( $\mathrm{Lu}$ et al., 2010). An eigenvector is a list of coefficients multiplying the original correlated variables to obtain new uncorrelated PCs, which are weighted linear combinations of the original variables. A matrix property, eigenvalue, is used to standardize the number of PCs that can be extracted. Usually, all the PCs with eigenvalues greater than 1 are considered as extracted PCs (Loska and Wiechuya, 2003; Lu et al., 2010).

PCA extracts the PCs from an $i, j$ matrix, where $i$ corresponds to the number of samples and $j$ to the number of pollutants measured (correlated variables, in this case all the heavy metal species measured) (Franco et al., 2015). The PC extracted corresponds to pollutant (i.e., heavy metal) sources. The number of PCs that can be extracted from the measurements depends on the variability of the available data and on the number of monitored substances. The first PC extracted includes the highest possible variability, and each succeeding compound accounts for as much as possible of the remaining variability (Han et al., 2006). The number of PCs that can be extracted depends on the retained variance of each PC (Franco et al., 2015). 
In this study, for the purpose of this exercise, a data matrix consisting of nine sites and six metals was considered (Rajaram et al., 2014). PCA was performed by applying varimax rotation with Kaiser's normalization with eigenvalues $>1$ to identify the sources of heavy metals in road dust. By extracting the eigenvalues and eigenvectors from the correlation matrix, the number of significant factors and the percent of variance explained by each of them were calculated. Data were checked for normality prior to PCA using Kolmogorov-Smirnova test and Shapiro-Wilk test, which indicated that the normalized data were suitable for PCA.

\subsection{Metal contamination assessment methods}

In this study, contamination factor index $\left(C_{f}^{i}\right)$, degree of contamination $\left(C_{d e g}\right)$, potential ecological risk index $(\mathrm{RI})$, pollution index $(\mathrm{PI})$ and integrated pollution index (IPI) were calculated to assess the metal contamination levels in the road dust. The road dust metal concentrations described in Rajaram et al. (2014) were also utilized to estimate metal contamination assessment.

Hakanson (1980) suggested four classes of $C_{f}^{i}$ and $C_{d e g}$, to evaluate the metal contamination levels. The degree of contamination $\left(C_{d e g}\right)$ is the sum of contamination factors for all of the elements. The contamination factor $C_{f}^{i}$ was defined as (Hakanson, 1980):

$C_{f}^{i}=C^{i} / C_{n}^{i}$

where $C^{i}$ is the mean content of metal and $C^{i}$ is the concentration of a reference value for individual metal. In this study, the $C^{i}{ }_{n}$ values represent the concentrations of the metals in the soil from a remote background area in India (Kuhad et al., 1989; Gowd et al., 2010).

The degree of contamination by the six heavy metals in road dust from the study areas was determined as follows (Hakanson, 1980):
$C_{d e g}=\sum C_{f}^{i}$

The classification for degrees of contamination suggested by Hakanson (1980) was based on eight pollutants, while there were only six heavy metals analyzed in this study. Thus, the original degree of contamination classification was adjusted according to Zhang et al. (2013). The modified classification is presented in Table I.

The assessment of degree of heavy metal pollution was carried out using the RI, based on the toxicity of metals and the response of the environment, as proposed by Hakanson (1980) according to the following equations:

$\mathrm{RI}=\sum E_{r}^{i}$

$E_{r}^{i}=T_{r}^{i} f^{i}$

$f^{i}=C^{i} / C^{i}$

where $E_{r}^{i}$ is the monomial potential ecological risk factor, $T_{r}^{i}$ is the metal toxic factor, $f^{i}$ is the metal pollution factor, $C^{i}$ is the concentration of metals in samples, and $C_{n}^{i}$ is a reference value for metals. The RI classification suggested by Hakanson (1980) was based on eight pollutants. In this study, a modified RI classification suggested by Zhang et al. (2013), was applied in order to evaluate the RI by the analyzed six heavy metals (Table II).

To assess the degree of metal contamination, a revised PI for each metal and an IPI of the six metals were estimated for each sampling site using the following equations as suggested by Huang (1987). PI was defined as follows and classified as presented in Table III:

$$
\begin{array}{ll}
\mathrm{PI}=C / X a & C \leq X a \\
\mathrm{PI}=1+(C-X a) /(X b-X a) & X a<C \leq X b
\end{array}
$$

Table I. Categories of contamination factors and contamination degree.

\begin{tabular}{lclcl}
\hline Class & $C_{f}^{i}$ value & Category & $C_{d e g}$ value & Category \\
\hline Class 1 & $C_{f}^{i}<1$ & Low contamination & $C_{d e g}<6$ & Low degree of contamination \\
Class 2 & $1 \leq C_{f}^{i}<3$ & Moderate contamination & $6 \leq C_{d e g}<12$ & Moderate degree of contamination \\
Class 3 & $3 \leq C_{f}^{i}<6$ & Considerable contamination & $12 \leq C_{d e g}<24$ & Considerable degree of contamination \\
Class 4 & $6 \leq C_{\mathrm{f}}^{i}$ & Very high contamination & $24 \leq C_{d e g}$ & Very high degree of contamination \\
\hline
\end{tabular}


Table II. Indices and grades of potential ecological risk of heavy metals contamination.

\begin{tabular}{lclcl}
\hline Class & $E^{i}{ }_{r}$ value & $\begin{array}{l}\text { Grades of ecological risk } \\
\text { of single metal category }\end{array}$ & RI value & $\begin{array}{l}\text { Grades of potential ecological } \\
\text { risk of the environment }\end{array}$ \\
\hline Class 1 & $E_{r}^{i}<40$ & Low risk & $\mathrm{RI}<50$ & Low risk \\
Class 2 & $40 \leq E^{i}{ }_{r}<80$ & Moderate risk & $50 \leq \mathrm{RI}<100$ & Moderate risk \\
Class 3 & $80 \leq E^{i}{ }_{r}<160$ & Considerable risk & $100 \leq \mathrm{RI}<200$ & Considerable risk \\
Class 4 & $160 \leq E_{r}{ }_{r}<320$ & High risk & $\mathrm{RI} \geq 200$ & High risk \\
Class 5 & $E_{r}^{i} \geq 320$ & High risk & & \\
\hline
\end{tabular}

Table III. Categories of pollution index and integrated pollution index of metals.

\begin{tabular}{|c|c|c|c|c|}
\hline Class & PI value & $\begin{array}{l}\text { Category of contamination } \\
\text { of single metal }\end{array}$ & IPI value & $\begin{array}{l}\text { Category of integrated contamination } \\
\text { index of the environment }\end{array}$ \\
\hline Class 1 & $\mathrm{PI} \leq 1$ & No contamination & $\mathrm{IPI} \leq 0$ & No contamination \\
\hline Class 2 & $1<\mathrm{PI} \leq 2$ & Low contamination & $0<\mathrm{IPI} \leq 6$ & Low contamination \\
\hline Class 3 & $2<\mathrm{PI} \leq 3$ & Moderate contamination & $6<$ IPI $\leq 18$ & Moderate contamination \\
\hline Class 4 & $\mathrm{PI}>3$ & High contamination & IPI $>18$ & High contamination \\
\hline
\end{tabular}

$$
\begin{array}{ll}
\mathrm{PI}=2+(C-X b) /(X c-X b) & X b<C \leq X c \\
\mathrm{PI}=3+(C-X c) /(X c-X b) & C>X c
\end{array}
$$

where $C$ is the measured concentration of specific metal, $X a$ is the threshold concentration of the metal enrichment, $X b$ is the threshold concentration of the low level of pollution and $X c$ is the threshold concentration of the high level of pollution. The values of $X a, X b$ and $X c$, were taken from Huang (1987) and Bai et al. (2009).

The IPI of all measured elements for each sample is defined below in Eq. (10) (Bai et al., 2009) as the sum of the difference between the individual element's PI and 1, and then classified (Bai et al., 2009) in Table III:

$\mathrm{IPI}=\sum(P I-1)$

\section{Results and discussion}

\subsection{Heavy metal concentrations}

Results on the concentrations of heavy metals in road dust samples collected from the study area and reported in Rajaram et al. (2014), were summarized and are presented in Fig. 2. The concentrations varied as follows: $\mathrm{Cd}$, from 1.9 to $3.8 ; \mathrm{Cr}$, from 56.4 to $500.3 ; \mathrm{Cu}$, from 87.3 to $499.0 ; \mathrm{Ni}$, from 27.2 to $61.7 ; \mathrm{Pb}$, from 69.0 to 316.0 , and $\mathrm{Zn}$ from 187.7 to $524.3 \mathrm{mg} \mathrm{kg}^{-1}$. The mean concentrations $\pm 95 \%$ confidence intervals of $\mathrm{Cd}, \mathrm{Cr}, \mathrm{Cu}, \mathrm{Ni}, \mathrm{Pb}$ and $\mathrm{Zn}$ in Delhi road dust were found to be $2.65 \pm 0.5,148.8 \pm 83.3,191.7 \pm 104.4$, $36.4 \pm 6.6,120.7 \pm 47.9$ and $284.5 \pm 67.6 \mathrm{mg} \mathrm{kg}^{-1}$, respectively. Metal concentrations found in this study were comparable to those observed by Rajaram et al. (2014).

Except $\mathrm{Zn}$, mean metal concentrations in the industrial areas $(\mathrm{Cd}, \mathrm{Cr}, \mathrm{Cu}, \mathrm{Ni}$ and $\mathrm{Pb}: 3.61,299.5$, $383.6,49.9$ and $236.5 \mathrm{mg} \mathrm{kg}^{-1}$, respectively) were relatively higher than those of other activity zones in Delhi (Rajaram et al., 2014). Industrial processes such as metallurgical, electroplating, chemical, and fuel combustion may be the main reasons for metal emissions in those industrial areas and high metal concentrations (Madrid et al., 2002; Wang and Qin, 2006; Li et al., 2008). The lowest concentrations of $\mathrm{Cd}, \mathrm{Cu}$ and $\mathrm{Ni}$ were found to be $1.9,58.3$ and $27.2 \mathrm{mg} \mathrm{kg}^{-1}$ near the highway, respectively, whereas the lowest $\mathrm{Cr}$ and $\mathrm{Pb}$ levels were found to be 56.4 and $69.0 \mathrm{mg} \mathrm{kg}^{-1}$ in residential areas, respectively. The average highest $\mathrm{Zn}$ concentration of $407.3 \mathrm{mg} \mathrm{kg}$ was found to be in mixed areas and lowest concentration of $187.7 \mathrm{mg} \mathrm{kg}^{-1}$ near highways. The highest $\mathrm{Zn}$ concentration found in mixed areas was comparable to that observed by Rajaram et al. (2014). In general, lower metal concentrations were obtained in the samples near the highways as compared to those obtained near the roads in other areas (Rajaram et al., 2014). This may be due to the fact that the roads are always jammed with the high vehicular traffic in other areas resulting in heavy metal emission and metal pollution 

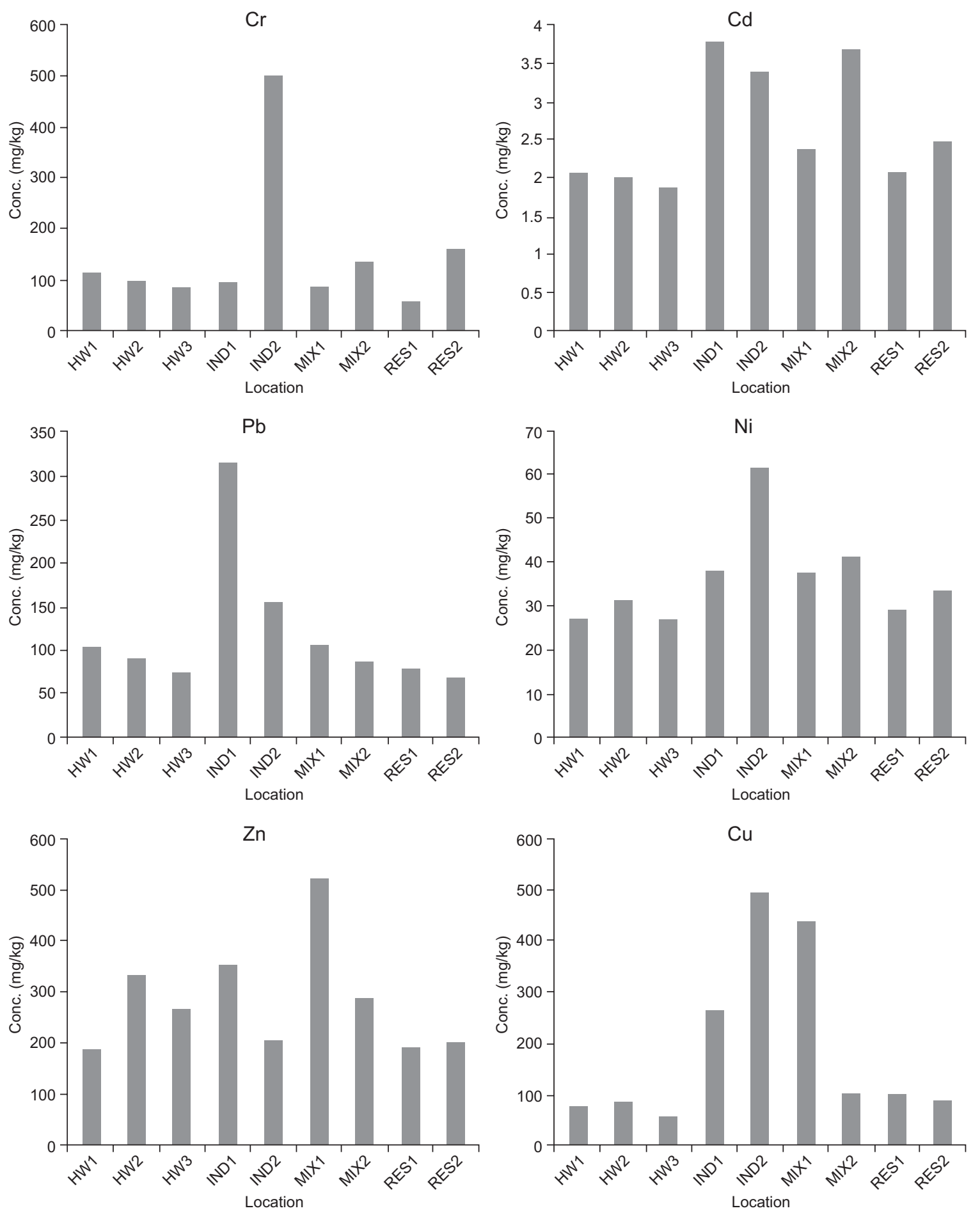

Fig. 2. Metal concentrations in road dust samples in Delhi. Concentration values of $\mathrm{Cr}, \mathrm{Pb}, \mathrm{Ni}, \mathrm{Zn}$ and $\mathrm{Cu}$ for HW1, HW2, HW3, IND1, IND2, MIX2 and RES2 are taken from Rajaram et al. (2014).

(Chen et al., 2010; Sun et al., 2010). The distribution of metals in different functional areas was comparable to the one observed by Wong et al. (1996), who reported that within the urban areas, industrial areas have the highest metal concentration, followed by commercial and residential districts. Wang and Qin (2006) also found that $\mathrm{Pb}$ concentration varied in different functional areas in Shenyang in the order of 
Table IV. Heavy metal concentrations $\left(\mathrm{mg} \mathrm{kg}^{-1}\right)$ in road dust in Delhi and various cities of the world.

\begin{tabular}{|c|c|c|c|c|c|c|c|c|}
\hline City & $\mathrm{Cd}$ & $\mathrm{Cr}$ & $\mathrm{Cu}$ & $\mathrm{Ni}$ & $\mathrm{Pb}$ & $\mathrm{Zn}$ & Size $(\mu \mathrm{m})$ & Reference \\
\hline Delhi & 2.65 & 148.8 & 191.7 & 36.4 & 120.7 & 284.5 & $<75$ & This study \\
\hline Birmingham & 1.62 & & 466.9 & 41.1 & 48 & 534 & $<63$ & Charlesworth et al. (2003) \\
\hline Ottawa & 0.37 & 43.3 & 65.84 & 15.2 & 39.05 & 112.5 & $100-250$ & Rasmussen et al. (2001) \\
\hline Calcutta & 3.12 & 54 & 44 & 42 & 536 & 159 & $<600$ & Chatterjee and Banerjee (1999) \\
\hline Hong Kong & 3.77 & & 173 & & 181 & 1450 & $<2000$ & Li et al. (2001) \\
\hline Shanghai & 1.23 & 159.3 & 196.8 & 83.9 & 294.9 & 733.8 & $<125$ & Shi et al. (2008) \\
\hline Luanda & & 26 & 42 & 10 & 351 & 317 & $<100$ & Ferreira Baptista and de Miguel (2005) \\
\hline Oslo & & & 123 & 41 & 180 & 412 & $<100$ & De Miguel et al. (1997) \\
\hline Madrid & & 61 & 188 & 44 & 1927 & 467 & $<100$ & De Miguel et al. (1997) \\
\hline Dhaka & & 104 & 46 & 26 & 74 & 154 & $<1000$ & Ahmed and Ishiga (2006) \\
\hline Kuala Lumpur & 2.9 & & 35.5 & & 2466 & 344 & $<63$ & Ramlan and Badri (1989) \\
\hline $\begin{array}{l}\text { Seoul } \\
\text { Indian natural soil }\end{array}$ & 3 & & 101 & & 245 & 296 & $<2000$ & Chon et al. (1995) \\
\hline $\begin{array}{l}\text { background } \\
\text { China soil }\end{array}$ & 0.9 & 114 & 56.5 & 27.7 & 13.1 & 22.1 & & Kuhad et al. (1989); Gowd et al. (2010) \\
\hline $\begin{array}{l}\text { guidelines }^{\mathrm{a}} \\
\text { Canada soil }\end{array}$ & 0.3 & 200 & 100 & 50 & 300 & 250 & & NEPA (1995) \\
\hline $\begin{array}{l}\text { Canada soil } \\
\text { guidelines } \\
\text { Canada soil }\end{array}$ & 10 & 64 & 63 & 50 & 140 & 200 & & CCME (2007) \\
\hline guidelines $^{\mathrm{c}}$ & 22 & 87 & 91 & 50 & 600 & 360 & & CCME (2007) \\
\hline
\end{tabular}

${ }^{\mathrm{a} C l a s s}$ II. Metal levels in class II are threshold values established to protect agricultural production and maintain human health.

${ }^{\mathrm{b}}$ Residential/parkland land use.

'Industrial land use.

industrial area $>$ commercial area $>$ residential area $>$ suburb. Since the ban of $\mathrm{Pb}$ in gasoline, the content of this element in the troposphere has decreased (Wang et al., 2003). The $\mathrm{Pb}$ concentration in road dust could still be attributed to emissions from fossil fuels, historical $\mathrm{Pb}$ contamination and the long half-life of $\mathrm{Pb}$ in soils (Wang et al., 2003; Saint' Pierre et al., 2004). The above results indicate that industrial and traffic activities were the main sources of metal pollution in road dust of Delhi.

Since no guidelines on metals in road dust or soil have been prescribed by regulatory authorities in India, results of this study were compared with the maximum permissible limits prescribed by China (NEPA, 1995) and Canada (CCME, 2007) for metals in soil. As shown in Table IV, the mean concentrations of $\mathrm{Pb}$ and $\mathrm{Ni}$ were lower than the guideline values of China and Canada, whereas the mean concentrations of $\mathrm{Cu}$ and $\mathrm{Zn}$ were higher than the permissible limits prescribed by those countries (Rajaram et al., 2014). The mean concentration of $\mathrm{Cd}$ was lower than values recommended by Canadian guidelines, but higher than Chinese guidelines, whereas the mean concen- tration of $\mathrm{Cr}$ was higher than the permissible limit prescribed by Canada but lower than the guideline value of China.

In comparison to documented studies, it was observed that the levels of heavy metals in the road dust of Delhi are comparable with those determined in other cities (Table IV) (Rajaram et al., 2014). In general, the concentration of $\mathrm{Pb}$ in Madrid and Kuala Lumpur, and $\mathrm{Zn}$ in Hong Kong were higher than the concentration recorded in Delhi road dust.

\subsection{Correlation coefficient analysis}

Pearson's correlation coefficient was estimated to evaluate the inter-element relationship of metals in road dust (Table V). The significant positive correlations $(>0.624)$ observed between $\mathrm{Ni}-\mathrm{Cr}-\mathrm{Cd}-\mathrm{Cu}$ indicate that the general contamination sources of these metals were primarily industrial and traffic activities (de Miguel et al., 1997; Lu et al., 2010; Rajaram et al., 2014). While $\mathrm{Pb}$ showed very weak positive correlations with $\mathrm{Cu}, \mathrm{Cr}, \mathrm{Ni}$ and $\mathrm{Zn}$ varying from 0.146 to 0.433 , a moderate correlation (0.660) was found between $\mathrm{Pb}$ and $\mathrm{Cd}$ thereby indicating 
Table V. Pearson's correlation coefficients between different metals.

\begin{tabular}{lcrrrrr}
\hline & $\mathrm{Cd}$ & $\mathrm{Cr}$ & $\mathrm{Cu}$ & $\mathrm{Ni}$ & $\mathrm{Pb}$ & $\mathrm{Zn}$ \\
\hline $\mathrm{Cd}$ & 1.000 & & & & & \\
$\mathrm{Cr}$ & 0.432 & 1.000 & & & & \\
$\mathrm{Cu}$ & 0.446 & 0.624 & 1.000 & & & \\
$\mathrm{Ni}$ & 0.682 & 0.901 & 0.796 & 1.000 & & \\
$\mathrm{~Pb}$ & 0.660 & 0.146 & 0.433 & 0.330 & 1.00 & \\
$\mathrm{Zn}$ & 0.096 & -0.304 & 0.438 & 0.026 & 0.244 & 1.000 \\
\hline
\end{tabular}

that the source for $\mathrm{Pb}$ may be industrial activities apart from the vehicular emissions (Rajaram et al., 2014). Zn showed poor correlation with all other metals except $\mathrm{Cu}$ (0.438), which may be due to the influence of traffic activities in these areas (Arslan, 2001; Gray et al., 2003).

\subsection{Principal component analysis}

The results of PCA indicated that all the elements are well represented by two components (Rajaram et al., 2014), which account for nearly $78 \%$ of the total variance for the data (Table VI). The initial component matrix indicated that $\mathrm{Ni}, \mathrm{Cu}$ and $\mathrm{Cd}$ are correlated, displaying high loading values in the first component (PC1) whereas Zn showed greater loading values in the second component (PC2) (Rajaram et al., 2014). $\mathrm{Cr}$ and $\mathrm{Pb}$ are partially represented in both $\mathrm{PC} 1$ and PC2. The rotation of the matrix eliminated ambiguities. As shown in Table VI, PC1 included Ni and $\mathrm{Cr}$; $\mathrm{PC} 2$ included $\mathrm{Zn}$, whereas $\mathrm{Cd}, \mathrm{Cu}$ and $\mathrm{Pb}$ are distributed in both $\mathrm{PC} 1$ and $\mathrm{PC} 2$. This implies that $\mathrm{Cu}, \mathrm{Ni}, \mathrm{Cd}, \mathrm{Cr}, \mathrm{Pb}$ and $\mathrm{Zn}$ can be defined as anthropogenic components and may originate from similar pollution sources such as particles released by industrial and traffic activities (Rawat et al., 2009; Lu et al., 2010). Cr and Ni are important constituents of many metal alloys (Siegel, 2002; Manno et al., 2006); therefore, the emission sources of these elements could be attributed to the metal processing industries (non-ferrous metal, electroplating, galvanizing, etc.) in the area. Although $\mathrm{Pb}$ has been banned as additive in petrol since a number of years, the concentration of $\mathrm{Pb}$ in urban road dust still reflects the significant degree of historical $\mathrm{Pb}$ contamination and the long half-life of $\mathrm{Pb}$ in soils. Some of the $\mathrm{Pb}$ in the road dust might have originate from particles emitted by industrial activities, whereas $\mathrm{Zn}$ and $\mathrm{Cu}$ may have been contributed by vehicular sources i.e. use of

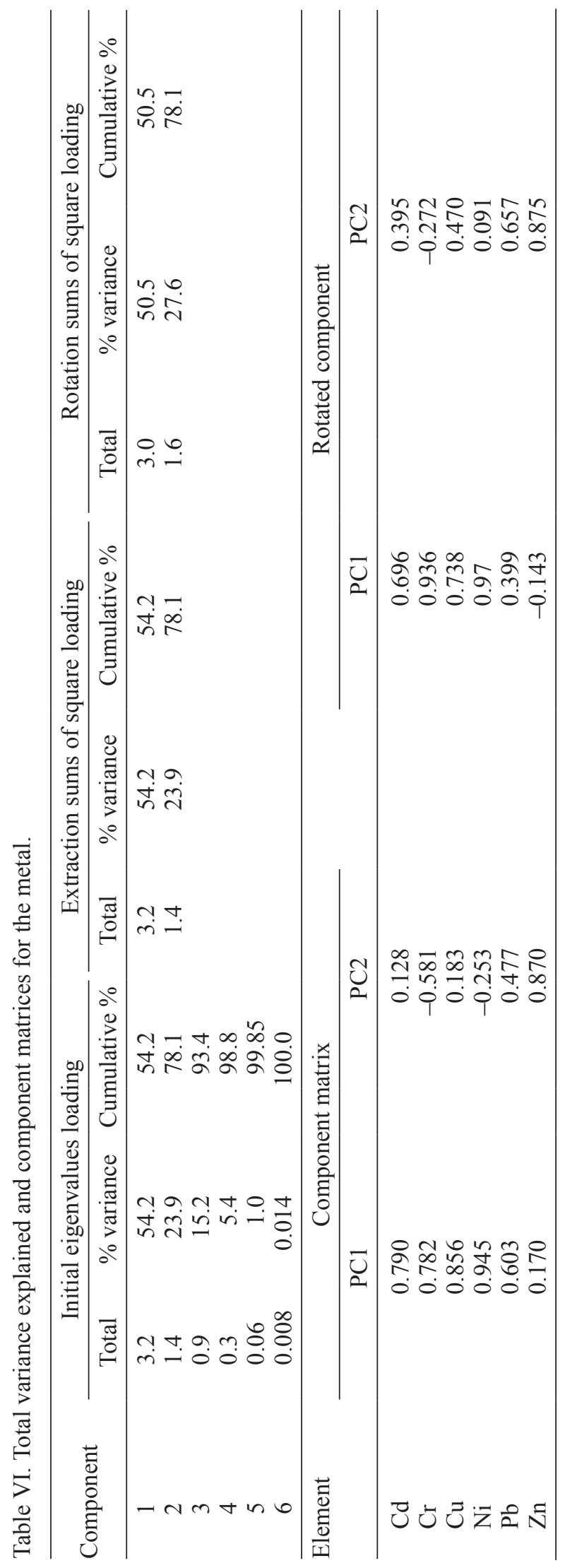


brake pads and wear and tear of tires (Saint' Pierre et al., 2004; Amato et al., 2009).

\subsection{Metal contamination assessment}

3.4.1 Contamination factor and degree of contamination

Contamination factor and the degree of contamination were estimated as suggested by Hakanson (1980) (Fig. 3). The contamination factors $\left(C_{f}^{i}\right)$ indicated very high contamination levels $\left(6 \leq C_{f}^{i}\right)$ of $\mathrm{Pb}, \mathrm{Zn}$ and $\mathrm{Cu}$, and considerable contamination levels $(3 \leq C f<6)$ of $\mathrm{Cd}$ and $\mathrm{Cr}$ in the road dust from the industrial areas. The road dust from the mixed areas had concentrations of $\mathrm{Cd}$ and $\mathrm{Cu}$ of considerable contamination and concentrations of $\mathrm{Zn}$ and $\mathrm{Pb}$ of very high contamination. In the road dust near the highways, the contamination factors indicated very high contamination by $\mathrm{Zn}$ and $\mathrm{Pb}$. The road dust from the residential areas had considerable contamination of $\mathrm{Pb}$ and very high contamination of $\mathrm{Zn}$. These results indicate that road dust is most significantly contaminated by $\mathrm{Zn}$ and $\mathrm{Pb}$, followed by considerable contamination by $\mathrm{Cu}$ and $\mathrm{Cd}$. The concentrations of $\mathrm{Cr}$ and $\mathrm{Ni}$ indicated moderate contamination of the road dust.

The proportions of the contamination of each metal to the total degree of contamination by the six heavy metals determined in the road dust samples are 6.0-14.4\% for $\mathrm{Cd}, 1.7-10.8 \%$ for $\mathrm{Cr}, 4.5-21.7 \%$ for $\mathrm{Cu}, 2.6-5.7 \%$ for $\mathrm{Ni}, 18.3-36.1 \%$ for $\mathrm{Pb}$, and 23.1 $54.7 \%$ for $\mathrm{Zn}$ (Fig. 4). The degree of contamination in road dust from highways, and industrial, mixed and residential areas are 24.2, 46.0, 36.5 and 20.8, respectively (Fig. 3). These results indicate that the

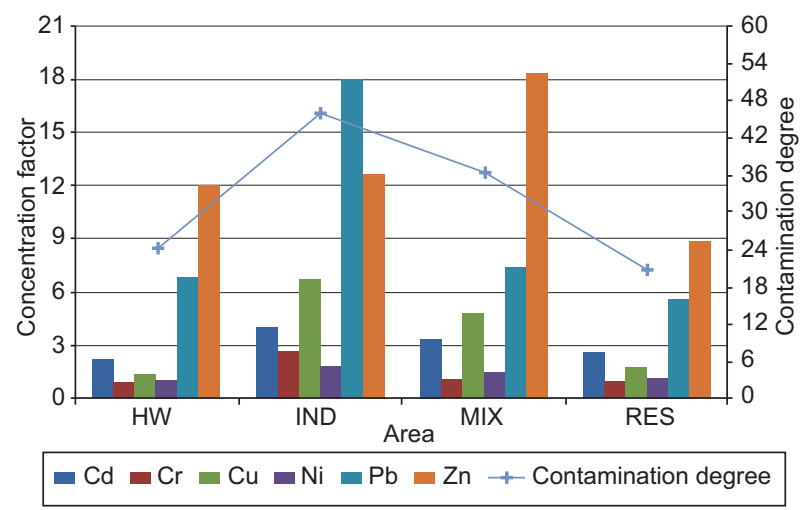

Fig. 3. Contamination factor and degree of contamination of road dust by heavy metals in different areas.

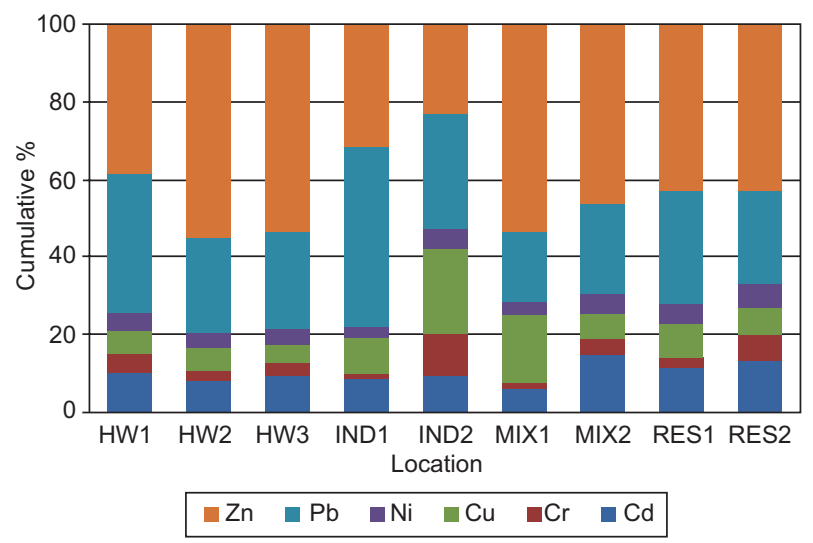

Fig. 4. Contribution of heavy metals to the degree of contamination.

road dust from the highways, the mixed areas and the industrial areas has a very high degree of contamination $\left(24 \leq C_{d e g}\right)$. Road dust from residential areas has a considerable degree of contamination $\left(12 \leq C_{d e g}<24\right)$. In particular, the degree of contamination for the mixed area 1 was much higher than the value at the other mixed area, which had lesser industrial units. These results indicate that industrial units might have contributed to the increased concentrations of heavy metals in road dust.

\subsubsection{Potential ecological risk index}

Results of ecological risk assessment of heavy metals in road dust (Fig. 5) revealed that the monomial risk indices $\left(E_{r}^{i}\right)$ of heavy metals were ranked in the following order: $\mathrm{Cd}<\mathrm{Pb}<\mathrm{Cu}<\mathrm{Zn}<\mathrm{Ni}<\mathrm{Cr}$. The average $E_{r}^{i}$ of $\mathrm{Cd}$ in samples from industrial and mixed areas is above 80 whereas the same average

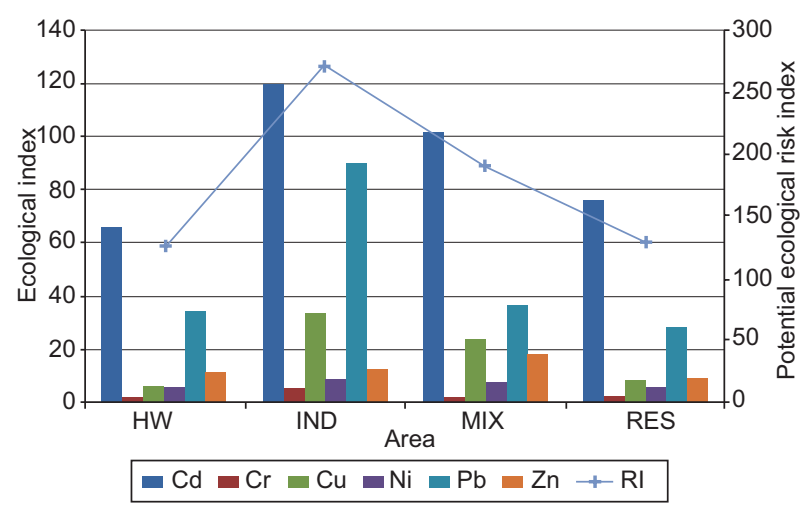

Fig. 5. Ecological risk index of heavy metals in road dust in different areas. 
can be found in residential areas, indicating that $\mathrm{Cd}$ poses a potentially considerable risk to the local ecosystem. The $E_{r}^{i}$ of $\mathrm{Pb}$ in road dust samples from the industrial area (90.3) poses considerable risk to the environments. $E_{r}^{i}$ values for the other metals were below 80, indicating low to moderate risk.

The overall RI of observed metals in road dust was calculated as the sum of all six risk factors (Fig. 5). RI in road dust ranged from 115.6 to 295.7 , with an average of 173.5. RI values were higher in the samples from industrial areas and vary between 246.8 and 295.7, indicating that there is a high potential ecological risk. Among different functional areas, the RIs pose high risk in industrial areas, and considerable risk in other areas.

The percent contribution of individual metal to overall RI is demonstrated in Fig. 6. It is shown that $\mathrm{Cd}$ accounted for most of the total risks, and the percentages ranged from $41.7 \%$ to $65.2 \%$ with a mean of $52.4 \%$. Pb ranked the second among the six metals contributing to the total risk, and the average

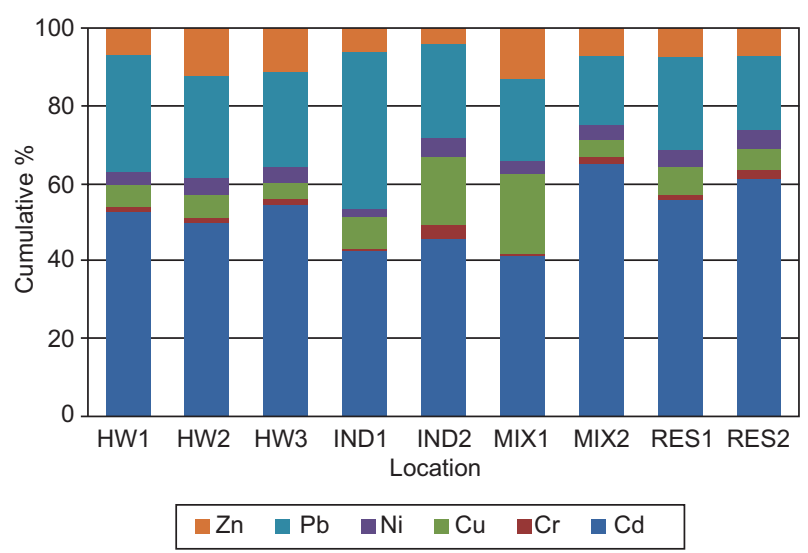

Fig. 6. Contribution of heavy metals to the potential ecological risk. was $25.5 \%$, which was followed by $8.9 \%(\mathrm{Cu}), 7.9 \%$ $(\mathrm{Zn}), 3.9 \%(\mathrm{Ni})$, and $1.5 \%(\mathrm{Cr})$. It could be concluded that the high ecological risk was primarily posed by two heavy metals, $\mathrm{Cd}$ and $\mathrm{Pb}$, as their contribution is nearly $78 \%$ of the total potentially ecological risk.

\subsubsection{Pollution index}

The minimum, maximum and mean values of PI for each metal are shown in Table VII. The mean PI values are generally high, indicating that there was serious pollution of road dust. However, PI values varied among metals. PI values of metals in road dust ranged as follows: $\mathrm{Cd}, 4.3$ to $7.0 ; \mathrm{Cr}, 0.6$ to $4.3 ; \mathrm{Cu}$, 2.0 to $3.3 ; \mathrm{Ni}, 0.7$ to $2.0 ; \mathrm{Pb}, 1.2$ to 2.3 , and $\mathrm{Zn}, 1.0$ to 3.1 with an average value of $5.3,1.6,2.4,0.9,1.4$ and 1.9, respectively. Most of the samples recorded middle or high pollution level PI values for $\mathrm{Cd}, \mathrm{Cu}$ and $\mathrm{Zn}$, indicating that urban road dust in Delhi is moderately to highly contaminated.

The PI values of metals were generally higher in industrial areas, indicating the presence of relatively serious heavy metal pollution (Fig. 7). Cd recorded high PI values in all the road dust samples from industrial areas, mixed use areas, residential areas and highways. PI of road dust from industrial areas indicated moderate contamination by $\mathrm{Cr}, \mathrm{Zn}$ and $\mathrm{Cu}$, whereas road dust from mixed-use areas had moderate contamination by $\mathrm{Zn}$ and $\mathrm{Cu}$. In highways and residential areas, the mean PI values of $\mathrm{Zn}$ and $\mathrm{Cu}$ were close to 2 . These findings suggest that the major sources of these metals may be vehicular emissions, and the mechanical parts and tires of vehicles as they are subjected to abrasion (Sadiq et al., 1989; Smolders and Degryse, 2002; Adachi and Tainosho, 2004).

The results showed the following proportions of heavy metal contamination levels (Table VII): $44.4,11.1$, and $88.9 \%$ of the road dust samples

Table VII. Statistical results of pollution index and integrated pollution index of metals.

\begin{tabular}{|c|c|c|c|c|c|c|c|c|c|c|c|c|c|c|}
\hline & \multicolumn{3}{|c|}{ PI } & \multicolumn{4}{|c|}{ Number of samples } & \multicolumn{3}{|c|}{ IPI } & \multicolumn{4}{|c|}{ Number of samples } \\
\hline & Min & Max & Mean & No. & Low & Moderate & High & Min & Max & Mean & No. & Low & Moderate & High \\
\hline $\mathrm{Cd}$ & 4.3 & 7.0 & 5.3 & 0 & 0 & 0 & 9 & & & & & & & \\
\hline $\mathrm{Cr}$ & 0.6 & 4.3 & 1.6 & 3 & 4 & 1 & 1 & & & & & & & \\
\hline $\mathrm{Cu}$ & 2.0 & 3.3 & 2.4 & 0 & 0 & 7 & 2 & & & & & & & \\
\hline $\mathrm{Ni}$ & 0.7 & 2.0 & 0.9 & 7 & 1 & 1 & 0 & & & & & & & \\
\hline $\mathrm{Pb}$ & 1.2 & 2.3 & 1.4 & 0 & 8 & 1 & 0 & & & & & & & \\
\hline $\mathrm{Zn}$ & 1.0 & 3.1 & 1.9 & 2 & 0 & 6 & 1 & 4.2 & 13.6 & 7.8 & 0 & 3 & 6 & 0 \\
\hline
\end{tabular}




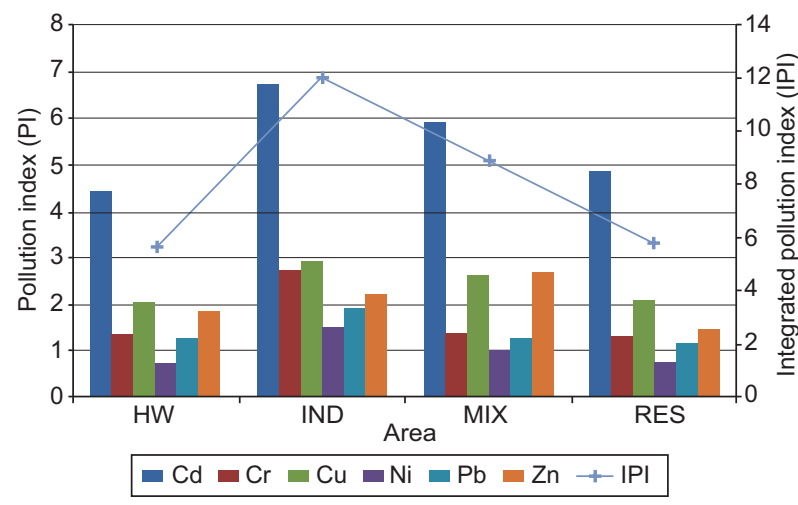

Fig. 7. Pollution index of road dust by heavy metals in different areas.

exhibited low contamination by $\mathrm{Cr}, \mathrm{Ni}$ and $\mathrm{Pb}$, respectively; $11,77.8,11.1,11.1$ and $66.7 \%$ of the samples were moderately contaminated by $\mathrm{Cr}, \mathrm{Cu}, \mathrm{Ni}$, $\mathrm{Pb}$, and $\mathrm{Zn}$, respectively, and 11.1, 22.2 and $11.1 \%$ of the samples were highly contaminated by $\mathrm{Cr}, \mathrm{Ni}$ and $\mathrm{Zn}$, respectively. All the samples were highly contaminated by $\mathrm{Cd}$. These results indicate that Delhi has an important contamination by $\mathrm{Cd}$ and a moderate contamination by $\mathrm{Cu}$ and $\mathrm{Zn}$. In addition, as shown in Fig. 7, all the roads in this study reported very high values of PI for $\mathrm{Cd}$ indicating that $\mathrm{Cd}$ contamination in road dust in Delhi is prominent. Furthermore, high ( $>1$ ) PI values were observed in only $22 \%$ of the samples for Ni. These data indicate that Ni pollution is relatively low in Delhi road dust when compared with other elements.

The IPI value of urban road dust varied from 4.2 to 13.6 with an average of 7.8 (Table VII). There was no sample with IPI $<1$, while low pollution levels with IPI lower than 6 accounted for about $33 \%$ of all samples. About $67 \%$ of all samples with IPI between 6 and 18 indicated moderate contamination. Thus, it is very likely that urban road dust in Delhi is moderately polluted with heavy metals.

Figure 8 shows the spatial distributions of $C_{d e g}$, RI, and IPI of the road dust of Delhi. It can be seen from this figure that five out of nine locations in this study had very high values ( $>24$ ) of $C_{d e g}$ while the remaining four locations also had higher values of $C_{d e g}$, close to 24 (very high contamination). RI levels at two locations, out of nine, showed high risk; whereas RI levels indicated considerable risk at all other locations, of which two locations are nearing high-risk category. Similarly, IPI at six locations showed moderate contamination and at remaining

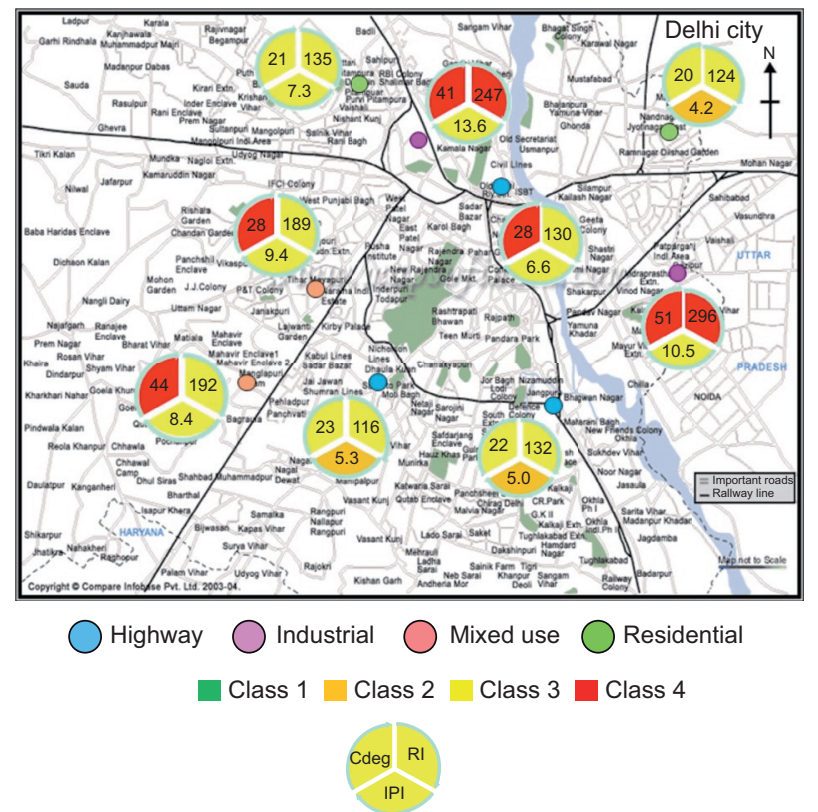

Fig. 8. Spatial distributions of degree of contamination, potential risk index and integrated pollution index in the road dust of Delhi.

three locations the IPI values are close to 6 (high contamination). It can be concluded that the road dust of Delhi has been highly polluted by anthropogenic emissions of heavy metals. These heavy metals can easily enter into human bodies through ingestion, inhalation and dermal contact and they can accumulate in the body and pose risks to human health, potentially causing serious problems at high levels. Therefore, strict heavy metal source control is essential to reduce heavy metal pollution in road dust in Delhi.

From the results of contamination factor evaluation, $\mathrm{Cd}$ is mainly in the moderately contaminated category. However, ecological risk caused by $\mathrm{Cd}$ was considerable due to its high toxicity. On the other hand, $\mathrm{Zn}$ accumulated significantly in the road dusts, but its ecological risk is relatively low. Pollution index results showed that road dust is highly contaminated with $\mathrm{Cd}$ and $\mathrm{Cu}$, however, $\mathrm{Cu}$ has not accumulated significantly as can be seen from estimated contamination factors, and its ecological risks are also relatively low. Thus, it can be seen that $C_{f}^{i}$ method mainly focused on the accumulation levels of individual metal without taking into account the toxic response factor. RI could describe both ecological risk caused by single pollutant and overall risk or contamination from different kinds of pollutants. PI estimation uses 
threshold concentrations and can be useful for comparing metal accumulation with the regulatory standards. Therefore, for environmental quality evaluation, all studied assessment methods are important.

\section{Conclusion}

The analysis of nine road dust samples from different activity zones in Delhi city indicated that the concentration of heavy metals in the road dust collected from industrial area are higher, especially $\mathrm{Ni}, \mathrm{Cr}$ and $\mathrm{Pb}$. This supports the results of source identification through statistical analysis, which indicates $\mathrm{Cd}, \mathrm{Cr}$, $\mathrm{Ni}$ and $\mathrm{Pb}$ in road dust may be of industrial origin, whereas vehicular traffic may be the major source of $\mathrm{Zn}$ and $\mathrm{Cu}$ (Rajaram et al., 2014). The metal contamination assessment results based on degree of contamination, potential ecological index and integrated pollution index, revealed that road dusts are mostly contaminated by $\mathrm{Zn}, \mathrm{Cd}$ and $\mathrm{Pb}$. The road dust from the industrial areas, mixed use areas and highways can be included under a very high degree of contamination with respect to the heavy metals, whereas the road dust from the residential area is having a considerable degree of metal contamination.

The results of the study indicated that the pollution level of road dust in Delhi city is in the category of "moderately to highly contaminated", and for environmental quality evaluation all assessment methods should be combined so that more comprehensive and accurate assessment results can be achieved. The findings of the study are based on the limited number of samples; however, a further comprehensive study is needed in order to better understand the metal contamination of road dust in Delhi and to develop environmental policies and strategies to minimize the contamination.

\section{Acknowledgments}

The authors express their gratitude to the Director of CSIR-NEERI, Nagpur, for encouragement and permission to publish the paper. Authors are also thankful to their colleagues who participated and provided support in the study.

\section{References}

Abrahams P. W., 2002. Soils: their implications to human health. Sci. Total Environ. 291, 1-32. doi:10.1016/ S0048-9697(01)01102-0.
Adachi K. and Y. Tainosho, 2004. Characterization of heavy metal particles embedded in tire dust. Environ. Int. 30, 1009-1017, doi:10.1016/j.envint.2004.04.004.

Ahmed F. and H. Ishiga, 2006. Trace metal concentrations in street dusts of Dhaka city, Bangladesh. Atmos. Environ. 40, 3835-3844, doi:10.1016/j.atmosenv.2006.03.004.

Amato F. M., M. Pandolfi, X. Viana, A. Querol, T. Alastuey and T. Moreno, 2009. Spatial and chemical Patterns of PM10 in road dust deposited in urban environment. Atmos. Environ. 43, 1650-1659, doi:10.1016/j. atmosenv.2008.12.009.

Arslan H., 2001. Heavy metals in street dust in Bursa, Turkey. J. Trace Microprobe Techn. 19, 439-445, doi:10.1081/TMA-100105058.

Bai J., B. Cui, Q. Wang, H. Ga and Q. Ding, 2009. Assessment of heavy metal contamination of roadside soils in Southwest China. Stoch. Environ. Res. Risk Assess. 23, 341-347, doi:10.1007/s00477-008-0219-5.

Banerjee A. D. K., 2003. Heavy metal levels and solid phase speciation in street dusts of Delhi, India. Environ. Pollut. 123, 95-105.

Bhanarkar A. D., D. G. Gajghate, P. S., Rao and P. Nema, 2005. Inventory of $\mathrm{SO}_{2}, \mathrm{PM}$ and toxic metals emissions from industrial sources in greater Mumbai, India. Atmos. Environ. 39, 3851-3864, doi:10.1016/j. atmosenv.2005.02.052.

Bhanarkar A. D., A. G. Gavane, D. S. Tajne, S. M. Tamhane and P. Nema, 2008. Composition and particle size distribution in particles emissions from a coal-fired power plant in India. Fuel 87, 2095-2101, doi:10.1016/j.fuel.2007.11.001.

Bilos C., J. C. Colomobo, C. N. Skorupka and M. J. Rodriguez Presa, 2001. Source distribution and variability of airborne trace metals in La Plata city area, Argentina. Environ. Pollut. 111, 149-158, doi:10.1016/S02697491(99)00328-0.

CCME, 2007. Canadian soil quality guidelines for the protection of environmental and human health. Canadian Council of Ministers of the Environment, Winnipeg.

Charlesworth S., M. Everett, R. McCarthy, A. Ordonez and E. de Miguel, 2003. A comparative study of heavy metal concentration and distribution in deposited street dusts in a large and a small urban area: Birmingham and Coventry, West Midlands, UK. Environ. Int. 29, 563-573, doi:10.1016/S0160-4120(03)00015-1.

Chatterjee A. and R. N. Banerjee, 1999. Determination of lead and other metals in a residential area of 
greater Calcutta. Sci. Total Environ. 227, 175-185, doi:10.1016/S0048-9697(99)00026-1.

Chen X., X. Xia, Y. Zhao and P. Zhang, 2010. Heavy Metal concentrations in road side soils and correlation with carbon traffic in Beijing, China. J. Hazard. Mater. 181, 640-646, doi:10.1016/j.jhazmat.2010.05.060.

Chon H. T., K. W. Kim and J. Y. Kim, 1995. Metal contamination of soils and dusts in Seoul metropolitan city, Korea. Environ. Geochem. Health 17, 139-146.

Cook A. D., P. Weinstein and J. A. Centeno, 2005. Health effects of natural dust. Biol. Trace Elem. Res. 103, 1-15, doi:10.1385/BTER:103:1;001.

De Miguel, E., J. F. Llamas, E. Chacón, T. Berg, S. Larssen, O. Royset and M. Vadset, 1997. Origin and patterns of distribution of trace elements in street dust: unleaded petrol and urban lead. Atmos. Environ. 31, 2733-2740.

Duzgoren-Aydin, N. S., 2007. Sources and characteristics of lead pollution in the urban environment of Guangzhou. Sci Total Environ. 385, 182-195, doi:10.1016/j. scitotenv.2007.06.047.

Ferreira-Baptista, L. and E. de Miguel, 2005. Geochemistry and risk assessment of street dust in Luanda, Angola: a tropical urban environment. Atmos. Environ. 39, 4501-4512, doi:10.1016/j.atmosenv.2005.03.026.

Franco J. F., J. Pacheco, L. C. Belalcázar and E. Behrentz, 2015. Characterization and source identification of VOC species in Bogotá, Colombia. Atmósfera 28, 1-11. GOI, 2002. Auto fuel policy report. Ministry of Petroleum and Natural Gas, Government of India, New Delhi.

GOI, 2011. Delhi population. Provisional population totals. Census of India. Government of India, New Delhi.

Government of NCT Delhi, 2010. State of environment report for Delhi, 2010. Department of Environment and Forest, Government of NCT Delhi, New Delhi, India, $137 \mathrm{pp}$.

Gowd S., S. Reddy and M. R. P. K. Govil, 2010. Assessment of heavy metal contamination in soils at Jajmau (Kanpur) and Unnao industrial areas of the Ganga Plain, Uttar Pradesh, India. J. Hazard. Mater. 174, 113-121, doi:10.1016/j.jhazmat.2009.09.024.

Gray C. W., R. G. McLaren and A. H. C. Roberts, 2003. Atmospheric accessions of heavy metals to some New Zealand pastoral soils. Sci. Total Environ. 305, $105-$ 115, doi:10.1016/S0048-9697(02)00404-7.

Gupta R. K., D. Majumdar, J. V. Trivedi and A. D. Bhanarkar, 2012. Particulate matter and elemental emissions from a cement kiln. Fuel Process. Technol. 104, 343-351, doi:10.1016/j.fuproc.2012.06.007.
Hakanson L., 1980. An ecological risk index for aquatic pollution control: A sedimentalogical approach. Water Res. 14, 975-1001, doi:10.1016/00431354(80)90143-8.

Han Y., P. Du, J. Cao and E. S. Posmentier, 2006. Multivariate analysis of heavy metal contamination in urban dusts of Xi'an, Central China. Sci. Total Environ. 355, 176-186, doi:10.1016/j.scitotenv.2005.02.026.

Huang R., 1987. Environmental pedology. Higher Education Press, Beijing, China.

Kuhad M. S., R. S. Malik, A. Singh and I. S. Dahiya, 1989. Background levels of heavy metals in agricultural soils of Indogangetic plains of Haryana. J. Indian Soc. Soil Sci. 3, 700-705.

Li X. D., C. S. Poon and P. S. Liu, 2001. Heavy metal contamination of urban soils and street dusts in Hong Kong. Appl. Geochem. 16, 1361-1368.

Li X., P. Li, X. Lin, Z Gong, S. Fan, L. Zheng and E. A. Verkhozina, 2008. Spatial distribution and sources of polycyclic aromatic hydrocarbons (PAHs) in soils from typical oil-sewage irrigation area, Northeast China. Environ. Monit. Assess. 143, 257-265, doi:10.1007/ s10661-007-9974-x.

Lienesch L. A., J. N. Dumont and J. A. Bantle, 2000. The effect of cadmium on oogenesis in Xenopus laevis. Chemosphere 41, 1651-1658, doi:10.1016/S00456535(00)00046-1.

Loska K. and D. Wiechuya, 2003. Application of principle component analysis for the estimation of source of heavy metal contamination in surface sediments from the Rybnik Reservoir. Chemosphere 51, 723-733, doi:10.1016/S0045-6535(03)00187-5.

Lu X., L. Wang, Y. Li, K. Lei, L. Huang and D. Kang, 2010. Multivariate statistical analysis of heavy metal in street dust of Baoji, NW China, J. Hazard. Mater. 173, 744-749, doi:10.1016/j.jhazmat.2009.09.001.

Madrid L., E. Díaz-Barrientos and F. Madrid, 2002. Distribution of heavy metal contents of urban soils in parks of Seville. Chemosphere 49, 1301-1308, doi:10.1016/ S0045-6535(02)00530-1.

Malinowski E. R., 2002. Factor analysis in chemistry. John Wiley and Sons, New York, 412 pp.

Manno E., D. Varrica and G. Dongarra, 2006. Metal distribution in road dust samples collected in an urban area close to a petrochemical plant at Gela, Sicily. Atmos. Environ. 40, 5929-5941, doi:10.1016/j.atmosenv.2006.05.020.

Massart D. L., B. G. M. Vanteginste, L. M. C. Buydens, S. De Jong, P. J. Lewi and J. Smeyers-Verbeke, 1997. 
Handbook of chemometrics and qualimetrics, vol. 20A. Elsevier, Amsterdam, 867 pp.

Mielke H. W. and P. L. Reagan, 1998. Soil is an important pathway of human lead exposure. Environ. Health Persp. 106, 217-229.

NEPA, 1995. Environmental quality standard for soils. GB 15618-1995, National Environmental Protection Agency of China, Beijing, China.

Rajaram B. S., P. V. Suryawanshi, A. D. Bhanarkar and C. V. C. Rao, 2014. Heavy metals contamination in road dust in Delhi City, India. Environ. Earth Sci. 72, 3929-3938, doi:10.1007/s12665-014-3281-y.

Ramlan M. N. and M. A. Badri, 1989. Heavy metals in tropical city street dust and roadside soils: A case of Kuala Lumpur, Malaysia. Environ. Tech. Lett. 10, 35-444.

Rasmussen P. E., K. S. Subramanian and B. J. Jessiman, 2001. Multi-element profile of house dust in relation to exterior dust and soils in the city of Ottawa, Canada. Sci. Total Environ. 267, 125-140.

Rawat M., A. L. Ramanathan and V. Subramanian, 2009. Quantification and distribution of heavy metals from small-scale industrial areas of Kanpur city, India. J. Hazard. Mater. 172, 1145-1149, doi:10.1016/j. jhazmat.2009.07.115.

Sadiq M., I. Alam, A. el-Mubarek and H. M. al-Mohdhar, 1989. Preliminary evaluation of metal pollution from wear of auto tires. Bull. Environ. Contam. Toxicol. 42, 743-748.

Saint' Pierre T. D., L. F. Dias, S. M. Maia and A. J Curtius, 2004. Determination of $\mathrm{Cd}, \mathrm{Cu}, \mathrm{Fe}, \mathrm{Pb}$ and $\mathrm{Tl}$ in gasoline as emulsion by electrothermal vaporization inductively coupled plasma mass spectrometry with analyte addition and isotope dilution calibration techniques. Spectrochim. Acta B. 59, 551-558, doi:10.1016/j. sab.2003.12.025.

Sezgin N., H. K. Ozcan, G. Demir, S. Nemlioglu and C. Bayat, 2003. Determination of heavy metal concentrations in street dusts in Istanbul E-5 highway. Environ. Int. 29, 979-985, doi:10.1016/S0160-4120(03)00075-8.

Shi G., Z. Chen, S. Xu, J. Zhang, L. Wang, C. Bi and J. Teng, 2008. Potentially toxic metal contamination of urban soils and roadside dust in Shanghai, China. Environ. Pollut. 156, 251-260, doi:10.1016/j.envpol.2008.02.027.
Siegel F. R., 2002. Environmental geochemistry of potential toxic metals. Springer, Heidelberg, Berlin, Germany, 218 pp.

Smolders E. and F. Degryse, 2002. Fate and effect of zinc from tire debris in soil. Environ. Sci. Technol. 36, 37063710, doi:10.1021/es025567p.

Sun Y., Q. Zhou, X. Xie and R. Liu, 2010. Spatial, sources and risk assessment of heavy metal contamination of urban soils in typical regions of Shenyang, China. J. Hazard. Mater. 174, 455-462, doi:10.1016/j. jhazmat.2009.09.074.

Tokalioglu S. and S. Karta, 2006. Multivariate analysis of the data and speciation of heavy metals in street dust samples from the organized industrial district in Kayseri (Turkey). Atmos. Environ. 40, 2797-2805, doi:10.1016/j.atmosenv.2006.01.019.

US-EPA, 1999. Compendium of Methods for the determination of inorganic compounds in ambient air. USEPA/625/R-96/010a. United States Environmental Protection Agency, Washington, D.C.

Waisberg M., P. Joseph, B. Hale and D. Beyersmann, 2003. Molecular and cellular mechanisms of cadmium carcinogenesis. Toxicol. 192, 95-117, doi:10.1016/ S0300-483X(03)00305-6.

Wang X. and Y. Qin, 2006. Spatial distribution of metals in urban topsoils of Xuzhou (China): Controlling factors and environmental implications. Environ. Geol. 49, 905-914, doi:10.1007/s00254-005-0122-z.

Wang X. D., Z. L. Xu, Z. L. Xie and Q. J. Yang, 2003. The change of plumbum content in TSP of Changchun ambient air before and after using lead-free gasoline. $J$. Jilin University (Science Edition) 41, 548-550.

Wong M. H., T. B. Chen and J. W. C. Wong, 1996. Trace metal contamination of the Hong Kong soil environment: A review. In: Contaminants and the soil environment in the Australasia-Pacific region ( $\mathrm{R}$. Naidu, R. S. Kookuna, D. P. Oliver, S. Rogers, M.J. McLaughlin, Eds.). Kluwer Acadenic Publishers, Dordrecht, 501-551.

Zhang J., H. Deng, D. Wang, Z. Chen and S. Xu, 2013. Toxic heavy metal contamination and risk assessment of street dust in small towns of Shanghai suburban area, China. Environ. Sci. Pollut. Res. 20, 323-332, doi:10.1007/s11356-012-0908-y. 